УДК 342.241:352.07(477)

https://doi.org/10.52058/2708-7530-2021-10(16)-56-66

Джигора Ольга Миколаївна кандидат економічних наук, доцент кафедри національної безпеки, публічного управління та адміністрування, Державний університет «Житомирська політехніка», вул. Чуднівська, 103, м. Житомир, 10005, e-mail: olia.bondarevska@gmail.com,_https://orcid.org/0000-0001-8490-3917

Джигора Дмитро Леонідович, заступник начальника - начальник відділу погашення боргу з фізичних осіб та заборгованості з ССВ управління по роботі 3 податковим боргом, Головне управління Державної податкової служби України в Житомирській області, 10003, м. Житомир, вулиця Юрка Тютюнника, 7, e-mail: dzhyhoradima@ukr.net, https://orcid.org/0000-0003-1109-6506

\title{
ПРОБЛЕМИ РОЗВИТКУ ТА ДІЯЛЬНОСТІ ОРГАНІВ МІСЦЕВОГО САМОВРЯДУВАННЯ В УКРАЇНІ
}

Анотація. У статті досліджено концептуальні проблеми реформування системи місцевого самоврядування в Україні. Наголошено, що на сьогодні питання реформування місцевого самоврядування в Україні стоїть досить гостро. Доведено, що органи місцевого самоврядування виступають важливим фактором демократизації суспільного життя, децентралізації управління та необхідною передумовою становлення громадянського суспільства. Визначено, що процеси конституційного реформування місцевого самоврядування $\epsilon$ найважливішим чинником розвитку всієї системи української державності. Виокремлено серед проблем діяльності органів місцевого самоврядування відсутність конституційного гарантування достатньої для реалізації повноважень економічної основи діяльності визнаних i зареєстрованих державою територіальних громад. Актуалізовано проблему формування та реалізації дієвої кадрової політики на місцях, удосконалення системи підготовки, перепідготовки, підвищення кваліфікації посадових осіб, службовців органів місцевого самоврядування, депутатів місцевих рад, запровадження професійних програм підготовки для органів місцевого самоврядування. Визначено, що в результаті проведення реформи децентралізації органи місцевого самоврядування отримали реальні ресурси для вирішення питань місцевого значення (житлово-комунального господарства, благоустрій території, місцеві соціально-економічні програми, проєкти, оновлення інфраструктури). Уточнено, що особливого значення для органів місцевого самоврядування набуває завдання зі створення точок економічного зростання як необхідної умови для їх збалансованого, рівномірного та самодостатнього соціально-економічного розвитку.

Ключові слова: органи місцевого самоврядування, реформа децентралізації, територіальна громада, проблеми, публічна влада, власні повноваження, делеговані повноваження

Dzhyhora Olha Mykolayivna Candidate of Economic Sciences, Associate Professor of the Department of National Security, Public Administration and Administration, Zhytomyr Polytechnic State University, St. Chudnivska, 103, Zhytomyr, 10005, e-mail: olia.bondarevska@gmail.com,https://orcid.org/0000-0001-8490-3917 
Dzhyhora Dmitry Leonidovich, Deputy Head - Head of the Department for Repayment of Debt from Individuals and Debts from the Unified Social Contribution of the Department for Dealing with Tax Debt, Main Department of the State Tax Service of Ukraine in the Zhytomyr Region, 10003, Zhytomyr, 7 Yurka Tyutyunnyka Street, e-mail: dzhyhoradima@ukr.net, https://orcid.org/0000-0003-1109-6506

\title{
PROBLEMS OF DEVELOPMENT AND ACTIVITY OF LOCAL GOVERNMENT IN UKRAINE
}

\begin{abstract}
The article examines the conceptual problems of reforming the system of local self-government in Ukraine. It is emphasized that today the issue of reforming local self-government in Ukraine is quite acute. It is proved that local governments are an important factor in the democratization of public life, decentralization of governance and a necessary prerequisite for the formation of civil society. It is determined that the processes of constitutional reform of local self-government are the most important factor in the development of the entire system of Ukrainian statehood. Among the problems of local selfgovernment activities is the lack of constitutional guarantee of sufficient for the implementation of the powers of the economic basis of the activities of recognized and registered by the state territorial communities. The problem of formation and implementation of effective personnel policy on the ground, improvement of the system of training, retraining, advanced training of officials, employees of local governments, deputies of local councils, introduction of professional training programs for local governments. It is determined that as a result of the decentralization reform, local governments have received real resources to address issues of local importance (housing and communal services, landscaping, local socio-economic programs, projects, infrastructure upgrades). It is specified that the task of creating points of economic growth as a necessary condition for their balanced, uniform and self-sufficient socio-economic development acquires special significance for local self-government bodies.
\end{abstract}

Keywords: local governments, decentralization reform, territorial community, problems, public authorities, own powers, delegated powers

Постановка проблеми. Сучасну демократичну державу неможливо уявити без повноцінного та дієвого механізму системи місцевого самоврядування. Місцеве самоврядування здійснюється територіальними громадами сіл, селищ, міст як безпосередньо, так і через сільські, селищні, міські ради та їх виконавчі органи, а також через районні та обласні ради, які представляють спільні інтереси територіальних громад сіл, селищ, міст. В Україні органи місцевого самоврядування $€$ невід'ємною складовою частиною системи публічної влади. У той же час як окремі елементи, так і система місцевого самоврядування в цілому ще не досягли того рівня впливу на економічний і гуманітарний розвиток громад і суспільства, який вони мають у більшості демократичних країн Європи і світу. Причиною цього $є$ як об’єктивні, так і суб'єктивні фактори. Можна констатувати, що на сьогодні в Україні накопичений великий досвід спеціалізованих досліджень 3 окремих проблем розвитку місцевого самоврядування.

Аналіз останніх досліджень і публікацій. Окремі аспекти політикоінституційного впливу на розвиток місцевого самоврядування вивчали вітчизняні та зарубіжні науковці. Зокрема, В. Куйбіда вивчав принципи й методи діяльності 
органів місцевого самоврядування, їх сучасний стан і визначив можливі напрями покращення їх роботи [1], Ю. Ключковський зробив істотний внесок у розробку концепцій реформування місцевого самоврядування [2]. Крім того, становлення та фінансове забезпечення розвитку місцевого самоврядування досліджувалося у працях відомих вітчизняних учених В. Антоненко, I. Бутко, В. Вакуленка, О. Васильєвої, В. Кравченка, О. Кириленко, В. Мамонової, Ю. Молодожен, М. Пухтинського, А. Ткачук, В. Удовиченко та інших. Проте, мають місце нерозв'язані проблеми регіонального управління та місцевого самоврядування, що вплинуло на формування такої системи організації влади, яка виявилася неспроможною забезпечити надання населенню якісних послуг, що відповідали б європейським стандартам.

Мета статті - дослідження проблем розвитку та діяльності органів місцевого самоврядування в Україні.

Виклад основного матеріалу. Практична реалізація державної регіональної політики безпосередньо залежить від реформування місцевого самоврядування та територіальної організації влади в Україні. Передусім йдеться про формування ефективного, дієвого самоврядування з утворенням відповідних інститутів та забезпечення його спроможності самостійно, за рахунок власних ресурсів вирішувати питання місцевого значення для створення сприятливого життєвого середовища, необхідного для всебічного розвитку людини, іiі самореалізації та захисту їі прав [3].

Органи місцевого самоврядування виступають важливим фактором демократизації суспільного життя, децентралізації управління та необхідною передумовою становлення громадянського суспільства. Завданням у державі щодо забезпечення ефективного регіонального розвитку $\epsilon$ надання широких повноважень органам місцевого самоврядування під власну відповідальність, що має бути регламентовано відповідним законодавством.

У науково-теоретичному аспекті місцеве самоврядування характеризується як особливий інститут, який у своїй основі має не державу чи державну владу, які засновані на матеріальній базі державної власності, а громадську спільноту, общину, матеріальною базою якої є зовсім інша форма власності - муніципальна.

Місцеве самоврядування являється специфічною формою реалізації природного права народу на владу та має особливого суб'єкта - територіальну громаду, тобто жителів села, селища та міста чи добровільного об'єднаних у територіальну громаду жителів кількох сіл. Територіальна громада здійснює місцеве самоврядування безпосередньо та через органи місцевого самоврядування, яке займає окреме місце в політичній системі держави.

Місцеве самоврядування на практиці втілює інтереси територіальних громад. При цьому роль місцевого самоврядування для процесів просторової організації публічної влади пояснюється тим, що влада територіальних громад, будучи самостійним видом публічної влади, за своїм суб'єктно-об'єктним складом, своєю природою та сутністю, діапазоном здійснюваних нею функцій 
є найбільш соціально орієнтованою формою здійснення публічної влади, а також виступає потужним каталізатором формування громадянського суспільства, оскільки свідома участьжителів у процесі утворення гідних умов життя на певній території сприяє формуванню у них відповідальності за вирішення місцевих проблем і тим самим підвищує їх загальну соціальну та громадянську активність [4].

В Україні закладено конституційні засади місцевого самоврядування, ратифіковано Європейську хартію місцевого самоврядування, прийнято низку законодавчих актів. Проте, незважаючи на право територіальних громад вирішувати питання місцевого значення, більшість із них неспроможна це робити через низьке ресурсне забезпечення, занепад або відсутність інфраструктури, брак кваліфікованих працівників тощо. Все це призводить до того, що левова частка питань місцевого значення наразі не вирішується належним чином.

До основних проблем розвитку органів місцевого самоврядування в Україні представлено в табл. 1.

Таблицุя 1

\section{Проблеми розвитку органів місцевого самоврядування}

\begin{tabular}{|c|c|}
\hline Проблема & Характеристика проблеми \\
\hline $\begin{array}{l}\text { Надмірна централізація } \\
\text { повноважень та фінансових } \\
\text { ресурсів }\end{array}$ & $\begin{array}{l}\text { Зумовила статус місцевого самоврядування } \\
\text { лише як номінального суб'єкта управління } \\
\text { місцевим розвитком }\end{array}$ \\
\hline $\begin{array}{l}\text { Відсутність чіткого розподілу } \\
\text { повноважень між державними } \\
\text { адміністраціями та органами } \\
\text { місцевого самоврядування }\end{array}$ & $\begin{array}{l}\text { Перешкоджає } \quad \text { побудові } \\
\text { механізму контролю над їх виконанням }\end{array}$ \\
\hline $\begin{array}{l}\text { Відсутність розподілу } \\
\text { повноважень (прав і } \\
\text { відповідальності) між різними } \\
\text { рівнями місцевого } \\
\text { самоврядування }\end{array}$ & $\begin{array}{l}\text { Призводить до їх дублювання, створює умови } \\
\text { для корупції та неефективного використання } \\
\text { бюджетних коштів }\end{array}$ \\
\hline $\begin{array}{l}\text { Погіршення якості та } \\
\text { доступності публічних послуг }\end{array}$ & $\begin{array}{l}\text { Унаслідок економічної } \\
\text { більшості органів місцевого самоврядування } \\
\text { здійснювати } \quad \text { власні } \text { й } \\
\text { повноваження }\end{array}$ \\
\hline $\begin{array}{l}\text { Неефективне управління та } \\
\text { нецільове використання } \\
\text { коштів, майна та інших } \\
\text { місцевих ресурсів }\end{array}$ & $\begin{array}{l}\text { Не сприяє забезпеченню фінансової } \\
\text { самостійності та спроможності територіальних } \\
\text { громад }\end{array}$ \\
\hline $\begin{array}{l}\text { Відсутність стандартів та } \\
\text { методології визначення } \\
\text { вартості публічних послуг }\end{array}$ & $\begin{array}{l}\text { Надання населенню органами місцевогı } \\
\text { самоврядування та органами виконавчо } \\
\text { влади, невизначеність на законодавчому рівн } \\
\text { умов для їх належного фінансування }\end{array}$ \\
\hline
\end{tabular}


Неврегульованість питань власності територіальних громад на землю

Призводить до неможливості
планувати розвиток територій,
громадськість далучати
управління землями різного цільовово
призначення та відстоювати власні інтереси у
процесі прийнятя рішень про використання
земельних ресурсів

Джерело: сформовано автором на основі [5].

Отже, питання реформування місцевого самоврядування, що сприятиме забезпеченню його спроможності самостійно, за рахунок власних ресурсів вирішувати питання місцевого значення, як ніколи на часі.

У результаті проведеного реформування основою нової системи місцевого самоврядування стали об'єднані територіальні громади, які утворилися на добровільній основі за законодавчо визначеною процедурою. У 2017 р. в Україні було створено 159 об'єднаних територіальних громад, у 2018 р. - 198, і на початок 2019 р. в державі налічується 367 ОТГ. Фактично об'єдналося 847 з 11 520 раніше діючих міських, селищних, сільських рад, або тільки 7,4\%. В 2020 р. повинно було завершитися створення ОТГ по всій країні.

Здавалося б, процес добровільного укрупнення одиниць базового рівня органів місцевого самоврядування мав забезпечити бажані результати реформування, сприяти становленню дієвої влади на місцях та вирішенню нагальних проблем. Однак на сучасному етапі реформування органів місцевого самоврядування та територіальної організації влади вже можна назвати низку ризиків, які виникли в результаті політичних компромісів під час ухвалення певних рішень чи нормативних актів або $\epsilon$ наслідком інституційної неспроможності окремих органів чи їхніх посадових осіб працювати в нових умовах і за новими правилами [6].

Так, зокрема, в уряді неодноразово наголошують на тому, що «основні принципи реформування - це добровільність та економічна ефективність», хоча при цьому європейські експерти зазначають, що «в жодній країні світу ... повністю добровільна система не призвела до успіху... Практично всі країни $\mathrm{CC}$, включно навіть із Монако, були вимушені пройти через стадію, на якій малі муніципальні одиниці вимушені були об'єднатися» [7].

Водночас, як показує практика, особисті мотиви очільників органів місцевого самоврядування, місцевих депутатів, керівників виконкомів, обласних рад аж ніяк не сприяють реалізації принципу щодо винятково добровільного об'єднання громад.

Окрім того, автори реформ органів місцевого самоврядування в Україні стверджують, що процес реформування буде розгортатися за прикладом Польщі, де відбулася корінна перебудова суспільного сектору, було досягнуто рівня публічної влади, характерного для розвинутих західних країн, що спричинило 
істотні позитивні перетворення в багатьох сферах громадського життя.

Однак, як слушно із цього приводу зазначає директор із питань науки та розвитку ГО «Інститут громадянського суспільства» А. Ткачук, «Україна вже вибрала не польський, а скандинавський досвід, тобто почала процес об'єднання як добровільний. Це може тривати як завгодно довго, але закінчиться все одно так, як закінчувалося всюди - обов'язковим, тобто примусовим, створенням нових адміністративно-територіальних одиниць» [8]. Тому цілком необхідним $\epsilon$ внесення змін до Конституції України стосовно відходу від положення щодо виключно добровільного об'єднання громад.

Але яким би шляхом не йшла Україна, необхідно пам'ятати, що будь-який позитивний досвід щодо проведення територіально-адміністративної реформи однієї країни не може бути механічно перенесений на терени іншої без урахування особливостей останньої. Без розробленої наукової, нормативноправової бази для впровадження дієвого самоврядування на місцях досягнути успіху буде складно.

Цілком можна погодитися 3 думкою польського економіста М. Желяка, що для успішного проведення реформ необхідна наявність трьох чинників: політичної волі еліти, готових експертних розробок i підтримки з боку суспільства [9].

Проведення реформ місцевого самоврядування потребуватиме належного кадрового забезпечення. Тому, на сьогодні, актуалізується проблема формування та реалізації дієвої кадрової політики на місцях, удосконалення системи підготовки, перепідготовки, підвищення кваліфікації посадових осіб, службовців органів місцевого самоврядування, депутатів місцевих рад, запровадження професійних програм підготовки для органів місцевого самоврядування тощо.

Процес створення об'єднаних територіальних громад вимагає також i розроблення нової чи коригування застарілої містобудівної документації (генеральних планів населених пунктів, схем територіального планування), оскільки органи місцевого самоврядування об'єднаних територіальних громад i досі мають обмежену юрисдикцію щодо цієї території. Система містобудівної документації побудована так, що ради територіальних громад можуть замовляти i затверджувати планувальну документацію виключно в межах населених пунктів, a за їх межами розроблення містобудівної документації $\epsilon$ компетенцією районного рівня. Все це ускладнює їхню діяльність щодо реалізації інфраструктурних проєктів між населеними пунктами, облаштування благоустрою, накладання штрафів на тих, хто завдає шкоди довкіллю на території громади, але поза межами поселень тощо. Тому першочерговим завданням у цьому плані $\epsilon$ внесення змін до існуючого законодавства. Важливою передумовою проведення територіально-адміністративної реформи, побудови демократичної держави $\epsilon$ фінансова незалежність органів місцевого самоврядування, оскільки розв'язання більшості фінансових питань саме на місцевому рівні є основою вирішення загальнодержавних соціально-економічних 
і політичних проблем у державі.

Право самостійно вирішувати органами місцевого самоврядування питання місцевого значення значною мірою залежить від законодавчо закріплених на постійній основі за місцевими бюджетами податків та зборів. Кошти від цих надходжень створили б реальні умови для виконання місцевою владою своїх повноважень та сприяли б децентралізації бюджетних ресурсів.

Вагомим кроком у здійсненні бюджетної децентралізації є прийняті в грудні 2014 р. Верховною Радою України зміни до Податкового і Бюджетного кодексів України, які дали змогу розширити права місцевих органів влади щодо формування доходів місцевих бюджетів i надали їм значну бюджетну самостійність [10].

У результаті внесених змін до українського законодавства органи місцевого самоврядування отримали реальні ресурси для вирішення питань місцевого значення (житлово-комунального господарства, благоустрій території, місцеві соціально-економічні програми, проєкти, оновлення інфраструктури тощо). Однак тільки розширення джерел наповнення місцевих бюджетів не дасть бажаних результатів без реально працюючої економіки.

Збільшення фінансових ресурсів на регіональному рівні, 3 одного боку, передбачає збільшення відповідальності, у тому числі перед власною громадою, а 3 іншого - сприяє породженню корупції. Для того щоб зменшити можливості чиновників для зловживань, необхідно, щоб інформація про планування та використання фінансових коштів була публічною. Не менш важливим моментом $\epsilon$ й залучення населення та громадських організацій до бюджетного процесу.

До переваг внесених змін до Бюджетного кодексу України доцільно віднести можливість органів місцевого самоврядування зберігати зекономлені кошти на кінець звітного періоду на власних рахунках та використовувати їх наступного року на противагу попередній практиці, коли ці кошти необхідно було використати і списати з рахунків до кінця року. Крім того, органи влади на місцях зможуть розміщувати тимчасово вільні кошти спеціального фонду місцевих бюджетів у комерційних банках. Це є вагомим стимулом для місцевої влади заощаджувати фінансові ресурси.

Проте, незважаючи на певні здобутки щодо впровадження бюджетної децентралізації, спостерігаємо й намагання центральної влади зберегти контроль над розподілом коштів державного бюджету.

Ураховуючи значне щорічне навантаження на місцеві бюджети, проєктом державного бюджету передбачені додаткові дотації, які йдуть на утримання закладів освіти та охорони здоров’я. При цьому подальший розподіл додаткової дотації між районними бюджетами та бюджетами об’єднаних територіальних громад відбуватиметься у порядку, визначеному обласними державними адміністраціями. Такий принцип не тільки не сприяє процесу децентралізації та створює корупційні ризики під час розподілу цих коштів, а й свідчить про намагання центральної влади і надалі зберігати контроль над розподілом коштів 
державного бюджету.

Крім того, у проєкті державного бюджету пропонують внести зміни наявного мотиваційного механізму горизонтального вирівнювання шляхом збільшення 3 50\% до 80\% обсягу вилучення коштів із місцевих бюджетів до державного (реверсна дотація). Це призведе до необгрунтованого зменшення місцевих бюджетів, які мають рівень надходжень податку на доходи з фізичних осіб на одного жителя вище 1,1. Така зміна механізму горизонтального вирівнювання позбавляє громади мотивації до нарощування фінансових ресурсів, адже чим більше фінансових ресурсів буде зароблено, тим більшу їх частину буде вилучено до державного бюджету в процесі горизонтального вирівнювання [11].

Проте, як i в минулі роки, мотиваційний механізм горизонтального вирівнювання може бути змінений й значна частина коштів передана для субвенції на соціально-економічний розвиток, розподіл якої відбувається непрозоро і в ручному режимі.

Підсумовуючи вищенаведене, можна констатувати таке:

1. Моніторинг реалізації реформи децентралізації в Україні показав незначні фактичні результати їі виконання, на цей час досі не створене повноцінне базове законодавство в частині повноважень, ресурсів, відповідальності. Крім цього, відсутнє секторальне законодавство, яке необхідне для реалізації реформи (в соціальній сфері, освіті, охороні здоров’я, дерегулюванні, промисловості, агропромисловому комплексі, сфері послуг, земельних відносин тощо).

2. Основною проблемою є затримка в термінах прийняття, в першу чергу змін до Конституції України, що надалі перешкоджає процесу прийняття інших законодавчих та нормативних документів, необхідних для проведення реформи.

3. Будь-які реформи в Україні необхідно проводити виходячи із потреб та цілей суспільства, чіткого розуміння того, який результат і місце у світовому співтоваристві хоче досягти Україна, що потребує розробки та затвердження комплексної національної стратегії розвитку країни.

4. Досвід децентралізації влади, реформування, організації і функціонування місцевого самоврядування у країнах світу, зокрема Польщі, для імплементації в Україні є позитивним, але дискусійним. Просте копіювання цих систем окремих країн світу не є доцільним, так як не враховує специфіку, індивідуальні особливості та наявний потенціал України та іiі регіонів.

5. Доцільним є глибоке науково-практичне дослідження світового й українського досвіду, розробка і впровадження науково обгрунтованої власної системи децентралізації влади 3 урахуванням історичних, ідеологічних, культурних, соціальних, економічних, географічних та інших особливостей країни, при цьому, враховуючи кращі світові практики, які результативно можна використовувати [8].

Слід зазначити, що невирішеним проблемним питанням для проведення вищезазначених досліджень діяльності органів місцевого самоврядування $\epsilon$ відсутність статистичної інформації по кожній територіальній громаді (паспорт 
громади), що ускладнює підведення щорічних підсумків діяльності.

Особливого значення для органів місцевого самоврядування набуває завдання зі створення точок економічного зростання як необхідної умови для їх збалансованого, рівномірного та самодостатнього соціально-економічного розвитку. Розвиток органів місцевого самоврядування передбачає:

1) структурну перебудову та диверсифікацію територіальних виробництв на якісно новій інноваційної основі, які будуть давати надходження до місцевих громад;

2) активізацію інвестиційного процесу;

Соціально-економічне значення формування точок економічного зростання полягає в такому:

1. Формування нового економічного укладу в органах місцевого самоврядування.

2. Будівництво доступного і комфортного житла, можливість для молоді отримання житла в оренду з правом викупу;

3. Будівництво сучасної розвинутої інфраструктури в місцевості: школи, дитячі садки, торгово-розважальні та культурні центри, стадіони тощо;

4. Забезпечення продовольчої безпеки країни, виробництво вітчизняної якісної продовольчої продукції за цінами, нижче ринкових;

5. Створення агрокластера з повним циклом «виробництво - переробка реалізація», що включає в собі сучасні високотехнологічні міні-ферми, переробні підприємства і широку мобільну мережу реалізації продукції [12].

Висновки. У період впровадження реформи децентралізації в Україні органи державної влади запропонували нові підходи та здійснили низку практичних кроків щодо вирішення проблемних питань органів місцевого самоврядування. Однією з важливих проблем органів місцевого самоврядування в Україні є запозичення світового досвіду, який був не досконало досліджений вищими органами влади для його впровадження та спонукає для більш детального його вивчення та імплементації у вітчизняну систему місцевого самоврядування. До суттєвих проблем розвитку органів місцевого самоврядування доцільно віднести також наступні: відсутність чіткого розподілу повноважень між державними адміністраціями та органами місцевого самоврядування, відсутність розподілу повноважень (прав і відповідальності) між різними рівнями місцевого самоврядування, погіршення якості та доступності публічних послуг, неефективне управління та нецільове використання коштів, майна та інших місцевих ресурсів, відсутність стандартів та методології визначення вартості публічних послуг, неврегульованість питань власності територіальних громад на землю. Можна стверджувати, що виокремлені проблеми розвитку місцевого самоврядування необхідно розглядати в контексті реформування органів місцевого самоврядування в процесі децентралізації влади в Україні. Щодо об’єктивного статусу органів місцевого самоврядування, то в період нових реформ він стає особливо помітним, оскільки йдеться про повне 
його перезавантаження, тобто зміну їх функцій, впливу, повноважень, структуру. При цьому органи місцевого самоврядування мають самостійно вирішувати та керувати системою місцевого самоврядування. Держава надала їм повне право та більш широкі повноваження щодо здійснення місцевого самоврядування, проте необхідно прийняти відповідні нормативно-правові акти задля вирішення вказаних вище проблем. Найбільш ефективне вирішення зазначених та інших проблем розвитку та діяльності місцевого самоврядування може бути здійснено комплексно лише через реформування системи публічної влади, адже без цього процесу та продовження реалізації реформи децентралізації неможливо подолати наявні проблеми та негативні явища в соціально-економічному розвитку держави та іiі регіонів, забезпечити підвищення рівня та якості життя населення.

\section{Лimepamypa:}

1. Куйбіда В. С. Принципи і методи діяльності органів місцевого самоврядування : монографія / В. С. Куйбіда. - К. : МАУП, 2004.

2. Ключковський Ю. Проблеми реформування місцевого самоврядування в Україні / Ю. Ключковський // Голос України. - 2005. - 29 лип.

3. Аналітична записка щодо аналізу процесу децентралізації в Україні та Польщі [Електронний ресурс]. - Режим доступу: http://dialog.lviv.ua/wp-content/uploads/2017/10/ Porivnyalniy-analiz-protsesudetsentralizatsiyi-Ukrayini-ta-Polshhi.pdf

4. Батанов О. В. Функції муніципальної влади: поняття та класифікація / О. В. Батанов // Бюлетень Міністерства юстиції України. - 2006. - № 11 (61). - С. 25-33.

5. Питання правового забезпечення модернізації державного управління та місцевого самоврядування в Україні / Заг. ред. Т.В. Мотренка, В.С. Воротіна. К. : Інститут законодавства Верховної Ради України, 2017. 197 с.

6. Основи децентралізації влади: методичні рекомендації / Д.О. Лукін, В.П. Гордієнко, Г.О. Мірошниченко та ін.; За ред Д.А. Лукіна. - Суми: ГО «Рада молодих вчених», 2015. - 144 с.

7. Мамонова В.В. Система місцевого самоврядування / В.В. Мамонова // Енциклопедія державного управління : у 8 т. / Нац. акад. держ. упр. при Президентові України ; наук.-ред. колегія : Ю.В. Ковбасюк (голова) та ін. - К. : НАДУ, 2011. - Т. 5. - 2011. - С. 342-344.

8. Моніторинг запровадження децентралізації в Україні - 2014-2019 роки [Електронний pecypc]. - Режим доступу: https://agropolit.com/ spetsproekty /510- monitoring-zaprovadjennyadetsentralizatsiyi-v-ukrayini--2014- 2018-rok.

9. Желяк М. Досвід Польщі: чому нове самоврядування «запрацювало» лише із другої спроби? [Електронний ресурс]. - Режим доступу: http: //www.evrointegration.com.ua/ articles/2014/12/8/7028546/view_print/

10. Урядовий портал. Єдиний веб-портал органів виконавчої влади України [Електронний ресурс]. - Режим доступу: https://www.kmu.gov.ua/

11. Збірник досліджень ефективності виконання державних програм / Швед. нац. Бюро аудиту ; Швед. ін-т держ. упр. - К., 2017. - 103 с.

12. Пархоменко-Куцевіл О. Формування, розвиток та модернізація державних посад: концептуально-методологічні засади : монографія /О. Пархоменко-Куцевіл. - К. : ФАДА, ЛТД, 2010. - 296 c.

\section{References:}

1. Kujbida, V. S. (2004). Principi i metodi dijal'nosti organiv miscevogo samovrjaduvannja [Principles and methods of local government] K.: MAUP [in Ukrainian]. 
2. Kljuchkovs'kij, Ju. (2005). Problemi reformuvannja miscevogo samovrjaduvannja v Ukraïni [Problems of local government reform in Ukraine]. Golos Ukraïni - Voice of Ukraine [in Ukrainian].

3. Analitichna zapiska shhodo analizu procesu decentralizaciï v Ukraïni ta Pol'shhi [Analytical note on the analysis of the decentralization process in Ukraine and Poland ]URL: http://dialog.lviv.ua/wp-content/uploads/2017/10/Porivnyalniy-analiz-protsesudetsentralizatsiyi-Ukrayinita-Polshhi.pdf [in Ukrainian].

4. Batanov, O. V. (2006). Funkciï municipal'noï vladi: ponjattja ta klasifikacija [unctions of municipal power: concept and classification]. Bjuleten' Ministerstva justiciï Ukraïni - Bulletin of the Ministry of Justice of Ukraine, 11 (61), 25-33 [in Ukrainian].

5. Motrenko, T.V., Vorotin, V.C. (2017). Pitannja pravovogo zabezpechennja modernizacii derzhavnogo upravlinnja ta miscevogo samovrjaduvannja v Ukraïni [i ssues of legal support for the modernization of public administration and local self-government in Ukraine] $\mathrm{K}$. : Institut zakonodavstva Verhovnoï Radi Ukraïni [in Ukrainian].

6. Lukin, D.A. (2015). Osnovi decentralizaciï vladi [Fundamentals of decentralization of power]. Sumi: GO «Rada molodih vchenih» [in Ukrainian].

7. Mamonova, V.V. (2011). Sistema miscevogo samovrjaduvannja [System of local selfgovernment]. K. : NADU [in Ukrainian].

8. Monitoring zaprovadzhennja decentralizaciï v Ukraïni - 2014-2019 roki [Monitoring of decentralization implementation in Ukraine - 2014-2019]. URL: https://agropolit.com/ spetsproekty/510- monitoring-zaprovadjennya- detsentralizatsiyi-v-ukrayini--2014- 2018-rok [in Ukrainian].

9. Zheljak, M. (2014). Dosvid Pol'shhi: chomu nove samovrjaduvannja "zapracjuvalo» lishe iz drugoï sprobi? [The experience of Poland: why the new self-government "earned" only on the second attempt?]. URL: http: //www.evrointegration. com.ua/articles/2014/12/8/7028546/view_print/ [in Ukrainian].

10. Urjadovij portal. Edinij veb-portal organiv vikonavchoï vladi Ukraïni [Government portal. The only web-portal of executive bodies of Ukraine] URL: https://www.kmu.gov.ua/ [in Ukrainian].

11. Zbirnik doslidzhen' efektivnosti vikonannja derzhavnih program (2017). K. [in Ukrainian].

12. Parhomenko-Kucevil, O. (2010). Formuvannja, rozvitok ta modernizacija derzhavnih posad: konceptual'no-metodologichni zasadi [Formation, development and modernization of public positions: conceptual and methodological principles]. K. : FADA, LTD, [in Ukrainian]. 